\title{
ACTION OF LEUCINE IN HEART HYPERTROPHY INDUCED BY THYROID HORMONE IN RATS
}

\author{
AÇÃO DA LEUCINA NA HIPERTROFIA CARDÍACA INDUZIDA PELO HORMÔNIO \\ TIREOIDIANO EM RATOS
}

\section{Thiago Montes FIDALE ${ }^{1}$; Alexandre GONÇALVES ${ }^{1}$; Eduardo Gaspareto HADDAD ${ }^{1}$; Fernanda Rodrigues de SOUZA ${ }^{1}$; Beatriz Montes FIDALE ${ }^{1}$; Fernando César VELOSO ${ }^{1}$; EImiro Santos RESENDE ${ }^{2}$}

1. Pós Graduação em Ciências da Saúde - PGCS, Universidade Federal de Uberlândia - UFU, MG, Brasil, thiagofidale@gmail.com; 2. Doutor em Medicina - UNIFESP, Professor da Faculdade de Medicina - FAMED-UFU e PGCS-UFU, Uberlândia, MG, Brasil.

\begin{abstract}
Leucine is a regulator of protein metabolism in vivo, but there is little information regarding its effect on hyperthyroidism-induced cardiac hypertrophy. This study aimed to verify the action of leucine in heart hypertrophy using an experimental model of hyperthyroidism in rats. A total of 40 Wistar rats were used and allocated randomly into four groups: control $(\mathrm{C})$, hormone $(\mathrm{H})$, leucine $(\mathrm{L})$ and hormone plus leucine (HL). Hyperthyroidism was induced by administering daily by gavage $20 \mu \mathrm{g}$ of levothyroxine sodium in aqueous suspension per $100 \mathrm{~g}$ of body weight, and leucine was supplemented by adding $5 \%$ of the amino acid to conventional food. After 28 days, the heart was removed and weighed; the left ventricle was separated along with the interventricular septum and weighed. Histological slides were made from the left ventricle and stained with hematoxylin-eosin to measure the transverse diameter of cardiomyocytes. Two-way analysis of variance (ANOVA) and Tukey post-test were used and significance level set at 5\%. There was a significant increase in the absolute heart weight, the left ventricular weight and cardiomyocyte diameter in rats of the $\mathrm{H}$ group compared to the other groups. The addition of leucine inhibited heart hypertrophy. Levothyroxine sodium-induced cardiac hypertrophy in Wistar rats is inhibited by leucine.
\end{abstract}

KEYWORDS: Hyperthyroidism. BCAA. Cardiac remodeling.

\section{INTRODUCTION}

Thyroid hormones induce a number of cardiac adaptations, including increased protein synthesis, activation of the metabolic pathways, changes in geometry of the heart chambers and neovascularization (FRANKLIN, K. G. 2001; KENESSEY, A. 2006). Such action occurs by direct effects on the myocardium and hemodynamic effects that modify the load on the heart (OJAMAA, K. 2010; CINI, G. 2009).

Leucine is an aliphatic branched-chain amino acid that acts as regulator of muscle protein metabolism in vivo (KOBAYASHI, H. 2006; KIMBALL, S. R. 2006). Escobar et al. studied the effects of leucine on the cardiac muscle of newborn pigs and their results suggest that postprandial leucine infusion acts as a nutritional signal to stimulate protein synthesis (ESCOBAR, J. 2005).

The leucine mechanism of action on protein metabolism occurs through the phosphorylation of protein kinase $\mathrm{p} 70 \mathrm{~S} 6 \mathrm{k}$, thereby inducing the phosphorylation of ribosomal protein (S6), the eukaryotic initiation factor (eIF4B) and elongation protein of translation process, eukaryotic elongation factor 2 kinase (eEF2k), thus affecting the initiation and elongation of mRNA classes (KIMBALL, S.R. 2006).

Heart failure is a common complication of hyperthyroidism, which causes different adjustments in accordance with the dose and duration of exposure to the hormone (KLEIN, I. 1994). A model of pathological cardiac hypertrophy is chronically observed in hyperthyroidism and is characterized by the inability to maintain cardiac output, relaxation deficit, contractile failure, and electrical instability (LOREL, B.H. 2000).

Studies in several experimental models using thyroid hormone have shown the involvement of the PI3K/AKT/mTOR pathway, where Triiodothyronine (T3) binds to TR $\alpha$ nuclear receptors, producing cardiac hypertrophy (KUZMAN, J.A. 2005; KENESSEY, A. 2006; DILLMANN, W. 2010).

However, the possible leucine protective effect on the myocardium by modulating protein synthesis through mTOR pathway may represent possible interventions in different conditions of heart damage, protecting the heart against the harmful effects triggered by hyperthyroidism (FIDALE, et al., 2013). In this context, the aim of this study was to analyze the leucine protective 
effect on the myocardium of rats submitted to experimental hyperthyroidism.

\section{MATERIAL AND METHODS}

\section{Animals}

Forty male Wistar rats with 10 weeks old and average weight of $370 \mathrm{~g}$ were used in the study. The animals were maintained in the Laboratory of Experimental Medicine of the Federal University of Uberlandia (UFU), where the study was conducted. Overall, the experimental period lasted 35 days, with the first seven days for a period of adaptation of animals to the laboratory and 28 days for experimentation. During the experimental period the laboratory ambient conditions were maintained constant with respect to temperature, noise level and brightness, with $12 \mathrm{~h}$ light and dark cycles. All animals had water ad libitum.

The 40 animals were divided randomly into four groups with 10 animals per group as follows: (C) control group, with free access to commercial food (RHOSTER ${ }^{\circledR}$, AIN-93G); (H) hormone group, under experimental hyperthyroidism and with free access to commercial food (RHOSTER ${ }^{\circledR}$, AIN93G); (HL) hormone plus leucine group, under experimental hyperthyroidism and with free access to commercial food (RHOSTER ${ }^{\circledR}, \quad$ AIN-93G) supplemented with 5\% leucine; and (L) leucine group, with free access to commercial food (RHOSTER $^{\circledR}$, AIN-93G), supplemented with 5\% leucine.

This study was approved by the Ethics Committee on Animal Use.

\section{Experimental hyperthyroidism}

All the animals in $\mathrm{H}$ and $\mathrm{HL}$ groups received daily by gavage the dose of $20 \mathrm{mg}$ of $0.01 \%$ levothyroxine sodium (T4) in aqueous suspension per 100 grams of body weight for 28 days. The solution was obtained from 10 tablets of $100 \mu \mathrm{g}$ levothyroxine sodium (T4) diluted in $10 \mathrm{ml}$ of distilled water (ENGELMAN, M.F.B. 2001). All animals in the $\mathrm{C}$ and $\mathrm{L}$ groups underwent the same procedure every day, but only getting the same amount of water instead of hormone solution.

\section{Blood collection and laboratory analyses}

After 28 days, all animals were weighed (AS 500 Marte ${ }^{\circledR}$ ) and anesthetized with a dose of $0.1 \mathrm{ml}$ of $10 \%$ ketamine hydrochloride and $2 \%$ xylazine hydrochloride per $100 \mathrm{~g}$ of body weight. Blood collection was made by cardiac puncture and later the animals were euthanized by exsanguination.
After cardiac puncture, blood samples were placed in VACUETTE® test tubes containing separating gel and taken to the Clinical Laboratory of the Veterinary Hospital of the UFU for analysis. For the determination of thyroid stimulating hormone (TSH) and T4 serum concentrations, INTERKIT® kits were used and the analyzes performed by enzyme-linked immunosorbent assays (ELISA)

\section{Morphometric and histological assays}

The heart was removed through thoracotomy, washed in distilled water and then weighed on a precision balance (Marte ${ }^{\circledR}$, AY220). After weighing, the organs were stored in $10 \%$ formalin for $72 \mathrm{~h}$ and subsequently the left ventricle was separated along with the interventricular septum and weighed.

The histological preparation was made including the material in paraffin block, which was cut in microtome with $5 \mu$ thickness, with two sections on each slide. Subsequently, sections were hydrated and the slides were stained with hematoxylin and eosin for analysis of cardiomyocytes. Five sections from each ventricle were obtained and, in each section, the diameters of five cells cut perpendicularly and identified in five different microscopic fields were measured. The measurements were made in blind conditions, that is, the prior identification of the sections with their respective groups was not allowed.

The measurements of cell diameters were performed in scanned images that were captured from a binocular microscope (Olympus BX40) with 40x lens, attached to a camera (Olympus OLY-200) and connected to a computer via digitizer board (Data Translation 3153). The measurements were made using the HL Image software (Western Vision).

\section{Statistical analysis}

All experimental data were expressed as mean \pm standard deviation. The normality ShapiroWilk test was used followed by analysis of variance of two factors (two-way ANOVA), complemented by the Tukey test, with 5\% significance level. All analyzes were made using the BioEstat ${ }^{\circledR}$ software (version 5.0).

\section{RESULTS}

There was no significant difference in total body weight of the animals at the end of the experiment in any groups. 
Table 1 shows the values for the absolute heart weight, left ventricule weight, transverse diameter of cardiomyocytes and serum T4 and TSH concentrations. Animals of the $\mathrm{H}$ group had significantly higher absolute heart weight as compared to other groups. The weight of the left ventricule was also significantly higher in animals of the $\mathrm{H}$ group when compared to the $\mathrm{C}$ group only. Likewise, animals of the $\mathrm{H}$ group showed significantly higher transverse diameter of cardiomyocytes than the other groups. In addition, animals of the HL and L groups presented higher cell diameter in relation to the $\mathrm{C}$ group (Table 1 , Figure 1).

Table 1. Heart and left ventricule weights

\begin{tabular}{|c|c|c|c|c|}
\hline \multirow{2}{*}{ Variables } & \multicolumn{4}{|c|}{$\begin{array}{l}\text { Groups } \\
(\mathrm{N}=40)\end{array}$} \\
\hline & $\begin{array}{c}\mathrm{C} \\
(\mathrm{N}=10)\end{array}$ & $\begin{array}{c}\mathbf{H} \\
(\mathrm{N}=10)\end{array}$ & $\begin{array}{c}\mathrm{HL} \\
(\mathrm{N}=10)\end{array}$ & $\begin{array}{c}\mathrm{L} \\
(\mathrm{N}=\mathbf{1 0})\end{array}$ \\
\hline Absolute heart weight, (g) & $1.46 \pm 0.06$ & $1.66 \pm 0.14 *$ & $1.51 \pm 0.12 \dagger$ & $1.44 \pm 0.10 \dagger$ \\
\hline Left ventricule weight, $(\mathrm{g})$ & $0.89 \pm 0.05$ & $\begin{array}{l}0.99 \pm \\
0.08^{*}\end{array}$ & $0.92 \pm 0.06$ & $0.91 \pm 0.10$ \\
\hline $\begin{array}{l}\text { Cardiomyocyte diameter, } \\
(\mu)\end{array}$ & $11327 \pm 195$ & $\begin{array}{c}13963 \pm \\
147^{*}\end{array}$ & $\begin{array}{c}12269 \pm 179 \\
* \dagger\end{array}$ & $\begin{array}{c}12033 \pm 85 \\
* \dagger\end{array}$ \\
\hline Serum T4, $(\mu \mathrm{g} / \mathrm{dl})$ & $4.76 \pm 0.83$ & $12.56 \pm 3.45^{*}$ & $12.46 \pm 2.32 *$ & $5.09 \pm 1.19$ \\
\hline Serum TSH, $(\mathrm{ng} / \mathrm{ml})$ & $1.45 \pm 0.35$ & $0.39 \pm 0.07 *$ & $0.42 \pm 0.08^{*}$ & $1.36 \pm 0.29$ \\
\hline
\end{tabular}

All values are expressed in mean \pm standard deviation; $\mathrm{C}$ : control; H: hormone; HL: hormone+leucine; L: leucine; *p $<0.05$ in relation to the $\mathrm{C}$ group and ${ }^{\dagger} \mathrm{p}<0.05$ in relation to the $\mathrm{H}$ group.

Serum T4 concentrations were significantly lower in animals of the $\mathrm{C}$ group as compared to the $\mathrm{H}$ and HL groups, whereas these latter had lower serum TSH concentrations than the $\mathrm{C}$ group (Table 1).

\section{DISCUSSION}

In hyperthyroidism models using Wistar rats to reproduce the cardiac pathology seen in hyperthyroidism and investigate the mechanisms of hypertrophy mediated by thyroid hormones, studies have shown an increase in heart weight as well as left and right ventricular hypertrophy (VAN LIERE, E.J. 1969; GERDES, A.M. 1987).

In the present study, the absolute heart weight and the left ventricule weight in rats of the $\mathrm{H}$ group with experimental thyrotoxicosis were significantly higher when compared to the control group, suggesting that the experimental model of hyperthyroidism applied for 28 days induced cardiac hypertrophy with an increase in weight of the heart and the left ventricle of rats. Hu et al. ${ }^{17}$ found similar results in rats under experimental hyperthyroidism, since after seven days of exposure to a dose of $100 \mu \mathrm{g}$ of T4/day/100 g body weight the animals had increase of $15 \%$ in both absolute heart weight and left ventricular weight when compared to the control group, in accordance with our findings (HU, L.W. 2003).

Changes in the transverse diameter of cardiomyocytes were also observed in the present study, with significantly higher values found in the $\mathrm{H}$ group as compared to the $\mathrm{C}$ group, indicating that the experimental hyperthyroidism model applied in rats for 28 days induced left ventricle hypertrophy. Regarding the effects of thyroid hormone in the cardiac tissue, it is important to emphasize that cardiac proteins responsive to the thyroid hormone are present in myocytes, which comprise a third of the total number of myocardial cells, thus representing the majority of cardiac proteins and ribonucleic acids present in the heart and accounting for $75 \%$ of the total myocardial volume (OPPENHIMER, J.H. 1987).

There was also an increase in the transverse diameter of cardiomyocytes in rats of the $\mathrm{L}$ and $\mathrm{HL}$ groups as compared to the control group. Accordingly, previous studies suggest that leucine acts as a nutritional signal to stimulate protein synthesis in the heart muscle, increasing the availability of the eukaryotic initiation factor (eIF4B), and activating the p70S6K and cardiac mTOR pathways (CANEDO, C.S. 2010).

An important finding of this study is the relationship between leucine and hyperthyroidisminduced cardiac hypertrophy. As the absolute heart weight and cardiomyocyte transverse diameter were significantly higher in rats of the $\mathrm{H}$ group than the HL group, these results indicate a probable action of leucine as an inhibitor of hyperthyroidism-induced cardiac hypertrophy. The clinical implications of these findings here described for the first time are still unknown. 
It is possible that leucine has an inhibitory effect on the thyroxine-induced PI3-K activity, an effect resulting from the activation of mTOR, which inhibits the signaling of thyroxine by phosphorylating the hormone receptor. However, leucine has no effect described in the phosphorylation of protein kinase B (PKB or Akt), which is involved in the thyroxine pathway. Interestingly, a similar effect was observed concerning leucine and insulin action (TREMBLAY, F. 2005; TORRES-LEAL, F.L.
2010), but any relationship with the mechanism of leucine are, at best, speculative.

\section{CONCLUSION}

The treatment of rats with thyroid hormone for 28 days induces heart hypertrophy and increased left ventricular weight. The association of leucine to the thyroid hormone appears to modulate cardiac hypertrophy that was induced in this experimental model, by still unknown mechanisms.

RESUMO: A leucina é um regulador do metabolismo proteico in vivo, e existem poucas informações referentes à sua ação na hipertrofia cardíaca induzida pelo hipertireoidismo. O estudo teve por objetivo verificar a ação da leucina na hipertrofia cardíaca de ratos Wistar em um modelo experimental de hipertireoidismo. Foram utilizados 40 animais, alocados ao acaso em quatro grupos, sendo: grupo controle $(\mathrm{C})$, grupo hormônio $(\mathrm{H})$, grupo leucina (L) e grupo hormônio + leucina (HL). O hipertireoidismo foi induzido administrando-se, diariamente, $20 \mu \mathrm{g} / 100$ gramas de levotiroxina sódica em suspensão aquosa, por gavagem e a leucina foi suplementada adicionando-se $5 \%$ do aminoácido à ração convencional. Ao final do período experimental, o coração foi removido e pesado. Foi separado o ventrículo esquerdo juntamente com o septo interventricular e pesado. Foram feitas lâminas histológicas a partir do ventrículo esquerdo, coradas com hematoxilina-eosina, para a medida do diâmetro transversal dos cardiomiócitos. Foi utilizada a análise de variância (ANOVA) de duas vias e pós-teste de Tukey e adotado um $\mathrm{P}<0,05$. Houve aumento significante para o peso do coração, peso do ventrículo esquerdo e diâmetro dos cardiomiócitos no grupo $\mathrm{H}$ em relação aos demais grupos. A adição de leucina inibe a hipertrofia. A hipertrofia cardíaca induzida em ratos Wistar pela levotiroxina sódica é inibida pela leucina.

PALAVRAS-CHAVE: Hipertireoidismo. BCAA. Remodelação cardíaca.

\section{REFERENCES}

CANEDO, C. S. et al. Activation of the cardiac mTOR/p70S6k pathway by leucine requires PDK1 and correlates with PRAS40 phosphorylation. Am J Physiol Endocrinol Metab, Bethesda, v. 298, p. 761-769, jan. 2010. http://dx.doi.org/10.1152/ajpendo.00421.2009

CINI, G. et al. Thyroid hormones and the cardiovascular system: pathophysiology and interventions. Biomed Pharmacother, Maryland Heights, v. 63, n. 10, p. 742-53, Dec 2009.

DILLMANN, W. Cardiac hypertrophy and thyroid hormone signaling. Heart Fail Rev, v. 15, n. 2, p. 125132, Mar 2010. http://dx.doi.org/10.1007/s10741-008-9125-7

ENGELMAN, M. F. B. et al. Estudo Morfométrico do Fígado de Ratos Submetidos a Doses Supra-Fisiológicas de Tiroxina. Arq Bras Endocrinol Metab, São Paulo, v. 45, n. 2, p. 173-179, 2001.

http://dx.doi.org/10.1590/s0004-27302001000200009

ESCOBAR, J. et al. DAVIS, T. A. Regulation of cardiac and skeletal muscle protein synthesis by individual branched-chain amino acids in neonatal pigs. Am J Physiol Endocrinol Metab, Bethesda, v. 290, p. 612-621, nov. 2005. http://dx.doi.org/10.1152/ajpendo.00402.2005

FIDALE, T. M. et al. Efeito da Leucina na Hipertrofia Cardíacae na Concentração Sérica de Creatina Quinase em Ratos Wistar em hipertireoidismo Experimental. Bioscience. J., Uberlândia, v. 29, n. 2, p. 499-505, Mar./Abr. 2013.

FRANCHINI, K. G. Hipertrofia cardíaca: mecanismos moleculares. Rev Bras Hipertens, Rio de Janeiro, v. 8, p. 125-42, 2001. 
GERDES, A. M.; MOORE, J. A.; HINES, J. M. Regional changes in myocyte size and number in propanololtreated hyperthyroid rats. Lab Invest, Kansas v. 57, p. 708-713, 1987.

HU, L. W. et al. Thyroxine-induced cardiac hypertrophy: influence of adrenergic nervous system versus reninangiotensin system on myocyte remodeling. Am J Physiol Regul Integr Comp Physiol, Bethesda, v. 285, p. 1473-1480, 2003. http://dx.doi.org/10.1152/ajpregu.00269.2003

KENESSEY, A.; OJAMAA, K. Thyroid hormone stimulates protein synthesis in the cardiomyocyte by activating the AKT-mTOR and p70S6k pathways. J Biol Chem, Maryland v. 281, n. 30, p. 20666-20672, Jul 28 2006. http://dx.doi.org/10.1074/jbc.M512671200

KIMBALL, S. R.; JEFFERSON, L. S. New functions for amino acids: effects on gene on transcription and translation. Journal of nutrition, Bethesda, v.83, n.2, p.500S-507S, 2006.

KLEIN I, OJAMAA K. Thyroid hormone and the cardiovascular system: from theory to practice. JClin Edndocrinol Metab, Bethesda, v. 78 p. 1026-7, 1994. http://dx.doi.org/10.1210/jcem.78.5.8175954 http://dx.doi.org/10.1210/jc.78.5.1026

KOBAYASHI, H. et al. Modulations of Muscle Protein Metabolism by Branched-Chain Amino Acids in Normal and Muscle-Atrophying Rats. Am Society for Nutrit, Bethesda, v. 136 n. 1, p. 234S-6S, jan. 2006.

KUZMAN, J. A. et al. L-Thyroxine activates AKT signaling in the heart. J Mol Cell Cardiol, v. 39, n. 2, p. 251-258, Aug 2005. http://dx.doi.org/10.1016/j.yjmcc.2005.03.020

LORELL, B. H, CARABELLO, B.A. Left ventricular hypertrophy. Pathogenesis, detection and prognosis. Circulation 102: 470-9, 2000. http://dx.doi.org/10.1161/01.CIR.102.4.470

OJAMAA, K. Signaling mechanisms in thyroid hormone-induced cardiac hypertrophy. Vascular Pharmacology, Los Angeles, v. 52, n. 3-4, p. 113-119, 2010. http://dx.doi.org/10.1016/j.vph.2009.11.008

OPPENHEIMER, J. H.; SCHWARTZ, H. L.; MARIASH, C. N. Advances in our understanding of thyroid hormone at the cellular level. Endocr Rev, Stanford University, v. 8 p. 288-308, 1987.

http://dx.doi.org/10.1210/edrv-8-3-288

TORRES-LEAL, F. L. et al. Aspectos atuais do efeito da leucina sobre o controle glicêmico e a resistência à insulina. Nutrire: rev. Soc. Bras. Alim. Nutr.= J. Brazilian Soc. Food Nutr, São Paulo, v.35, 2010.

TREMBLAY, F. et al. A. Activation of the mammalian target of rapamycin pathway acutely inhibits insulin signaling to AKT and glucose transport in 3T3-L1 and human adipocytes. Endocrinology, Stanford, v. 146, n. 3, p. 1328-1337, 2005. http://dx.doi.org/10.1210/en.2004-0777

VAN LIERE, E. J.; SIZEMORE, D. A.; HUNNELL, J. Size of cardiac ventricles in experimental hyperthyroidism in the rat. Proc Soc Exp Biol Med, Upstake, v. 132 p. 663-665, 1969. 